\title{
Evaluation of faecal contamination in Bahía Blanca estuary (Argentina) using a numerical model
}

\author{
Evaluación de la contaminación fecal en el estuario de Bahía Blanca (Argentina) \\ aplicando un modelo numérico
}

\author{
Jorge O. Pierini ${ }^{1}$, María E. Streitenberger ${ }^{2}$ and Mónica D. Baldini ${ }^{2}$
}

\begin{abstract}
${ }^{1}$ Comisión de Investigaciones Científicas, Departamento de Física, Universidad Nacional del Sur, Centro Científico y Tecnológico de Bahía Blanca, Casilla Correo 804, 8000 Bahía Blanca, Argentina. jpierini@criba.edu.ar ${ }^{2}$ Departamento de Biología, Bioquímica y Farmacia, Universidad Nacional del Sur, San Juan 670, 8000 Bahía Blanca, Argentina
\end{abstract}

\begin{abstract}
Resumen.- Es conocida la necesidad de contar con técnicas y sitios adecuados para la eliminación de efluentes cloacales. El lugar más utilizado para la descarga de los mismos, tratados o no, es un cuerpo de agua cercano. En Bahía Blanca en septiembre de 2008 comenzó a operar una planta de tratamiento de efluentes cloacales que vuelca los líquidos insuficientemente tratados en el área cercana a una pileta Municipal (Balneario Maldonado). Debido a la proximidad, una parte importante de las aguas residuales podría alcanzar dicha pileta con el correspondiente riesgo sanitario. La finalidad de este estudio fue evaluar la salud de las aguas de la parte interna del estuario de Bahía Blanca, aplicando un modelo numérico (MOHID), utilizando como indicador de contaminación fecal la bacteria Escherichia coli. Se validó el modelo de dispersión de contaminación fecal, de modo de poder utilizarlo como una herramienta integral de gestión. EI MOHID utilizó el concepto de trazadores lagrangianos para evaluar la evolución espacio-temporal de la pluma de contaminación, determinada por el régimen de mareas, vientos y la circulación local. El modelo predijo con precisión la variabilidad y los recuentos medios de los microorganismos indicadores en la mayoría de los sitios muestreados $(r>0,9)$ y muestran el impacto ambiental sobre la pileta Municipal. Se espera que las simulaciones del modelo MOHID descritas en este documento sean una herramienta útil y de esta manera generar un esfuerzo por parte de las autoridades competentes para reducir la contaminación en el estuario de Bahía Blanca.
\end{abstract}

Palabras clave: Aguas estuarinas, descarga de efluentes cloacales, dispersión de Escherichia coli, modelo lagrangiano

\begin{abstract}
The need for techniques and appropriated sites for sewage discharge has been long time acknowledged. The most common place to discharge wastewater treated or not, is usually a nearby body of water. In September 2008 began operating a sewage treatment plant in Bahía Blanca that dumps poorly treated wastewater in the area near Municipal public recreational pool (Balneario Maldonado). Due to proximity, there is a potential health risk because a significant part of this sewage could reach the Municipal pool. The purpose of this study is to assess the health of the marine water bodies along the inner part of Bahía Blanca estuary using a numerical model (MOHID), with special attention to a specific indicator of faecal contamination, Escherichia coli. We validated the dispersion model of faecal contamination, so that we can use it as a decision support tool in coastal areas. MOHID model used the concept of lagrangian tracers to evaluate the spatial-temporal evolution of the pollution plume, determined by tidal regime, winds and local circulation. The fate models accurately predicted both variability and means indicator organism counts at most stations $(r>0.9)$ and show the environmental impact over the Municipal pool. It is expected that the model results described herein be a useful tool and thereby generate an effort by environmental authorities to reduce pollution in the Bahía Blanca estuary.
\end{abstract}

Key words: Estuarine waters, coastal sewage discharge, Escherichia coli dispersion, lagrangian model

\section{INTRODUCTION}

The need for techniques and appropriated sites for sewage discharge has been long time acknowledged. The most common place to discharge wastewater treated or not, is a nearby body of water. Communities located in estuarine and coastal areas have several alternatives for disposal their wastewater: direct discharge into the sea through submarine outfalls, in the watercourses and tributaries feeding the estuary, and directly in the 
estuarine waters. The availability of a nearby water body leads many communities to discharge untreated or partially treated wastewater into estuarine and coastal waters. A basic assumption is made that dilution can lessen pollution-related problems (Burkhardt III et al. 2000, Chigbu et al. 2005). However, mixing in coastal waters is far from complete and in estuaries even less complete, thus leading sometimes to the presence of plumes with high concentration of polluting agents (Malhadas 2008, Viegas et al. 2009). In more stagnant areas the wastewaters can promote the formation of hotspots in the immediate vicinity of the discharge point, where concentrations rise to significant levels.

Domestic wastewater contains a large number of pathogenic microorganisms originating from humans who are infected or who are carriers of a particular disease. The most common pathogens found in sewage are those that cause typhoid fever, dysentery and gastroenteritis (Soller et al. 2010). The faecal coliform group and particularly the bacteria Escherichia coli (EC) are usually used as a proxy for pathogenic agents in wastewater (Fries et al. 2006).

The faecal pollution in the Bahía Blanca area is a common challenge shared with many other Argentinian coastal systems. While in Argentina there are no epidemiological studies (Subsecretaria de Recursos Hídricos de la Nación 2001¹, Rodriguez et al. 2002), it is known that during swimming and other recreational activities in which there is an involuntary swallowing of water the risk of gastrointestinal diseases, as well as respiratory, eye, ear and skin infections increases (Kay et al. 1994, Fleisher et al. 1996, Rossen et al. 2008). Then, knowing the levels of indicator organisms in recreational waters are important for assessing disease risk associated with their use (Martins et al. 1995, Field \& Samadpour 2007).

Bahía Blanca city has a public swimming pool (called Balneario Maldonado) that is filled with water from the estuary of the same name. It is one of the few places along the coast where the people have free access. In September 2008 a treatment plant in the area near to Balneario Maldonado began to dump $\left(200 \mathrm{~m}^{3} \mathrm{~h}^{-1}\right)$ of inadequately treated sewage (Fig. 1).
This type of contamination has not been deeply studied, some have pointed out the need for such analysis because of the high and increasing density of EC in the waters of the estuary (Pierini 2007, Pierini et al. 2008, Streitenberger \& Baldini 2010). The presence of large volumes of raw sewage creates a considerable anthropogenic pressure on the aquatic environment, affecting the biota as well as human health (Pierini et al. 2008).

The domestic sewage dumping in estuarine channels has been classified as a potential source of pollution in Bahía Blanca estuarine system. The extent and the degree of contamination as well as the residence time of microbiological contamination had already been observed (Pierini et al. 2008). Numerical models are very useful to estimate contaminant dispersion, particularly faecal coliforms, because they can combine hydrodynamic and water quality processes (Frick et al. 2001).

The main objective of this work was to present the methodology, based on the MOHID model system (Coelho et al. 2002, Leitao et al. 2008, Mateus \& Fernandes 2008, Pierini et al. 2008), to assess the health of the marine water bodies along the inner part of Bahía Blanca estuary, with special attention to a specific indicator of faecal contamination, EC and aiming to validate a faecal decay model for the Bahía Blanca Estuary so it can be used as a decision support tool in coastal areas.

\section{Materials ANd Methods}

\section{STUDY AREA DESCRIPTION}

Bahía Blanca is a mesotidal coastal-plain estuary located in the south of the Buenos Aires Province, Argentina. It consists of a series of NW-SE channels separated by islands and wide tidal flats (Fig. 1), which are the remanents of a late Pleistocene - early Holocene delta, and has an area of $1150 \mathrm{~km}^{2}$ (Melo 2004). The estuary has an elongated shape with a total length of $68 \mathrm{~km}$, being 200 $\mathrm{m}$ and $4 \mathrm{~km}$ wide near its head and mouth, respectively. Its mean depth is $10 \mathrm{~m}$, although values of the order of $22 \mathrm{~m}$ are found at the mouth of the estuary (Pierini 2007). The circulation in the estuary in general, and in the main channel in particular, is dominated by semidiurnal and

\footnotetext{
${ }^{1}$ Subsecretaria de Recursos Hídricos de la Nación. 2001. Niveles guía de calidad de agua ambiente para recreación humana con contacto directo correspondientes a Escherichia coli/ Enterococos. 7 pp. [on line] <http://www.pnuma.org/agua-miaac/ CODIA CALIDAD DE LAS AGUAS/MATERIAL ADICIONAL/PONENCIAS/PONENTES/Tema 5 Niveles Guias Calidad de Aguas/NIVELES GUIA/4 - Desarrollos/escherichia.pdf>
} 


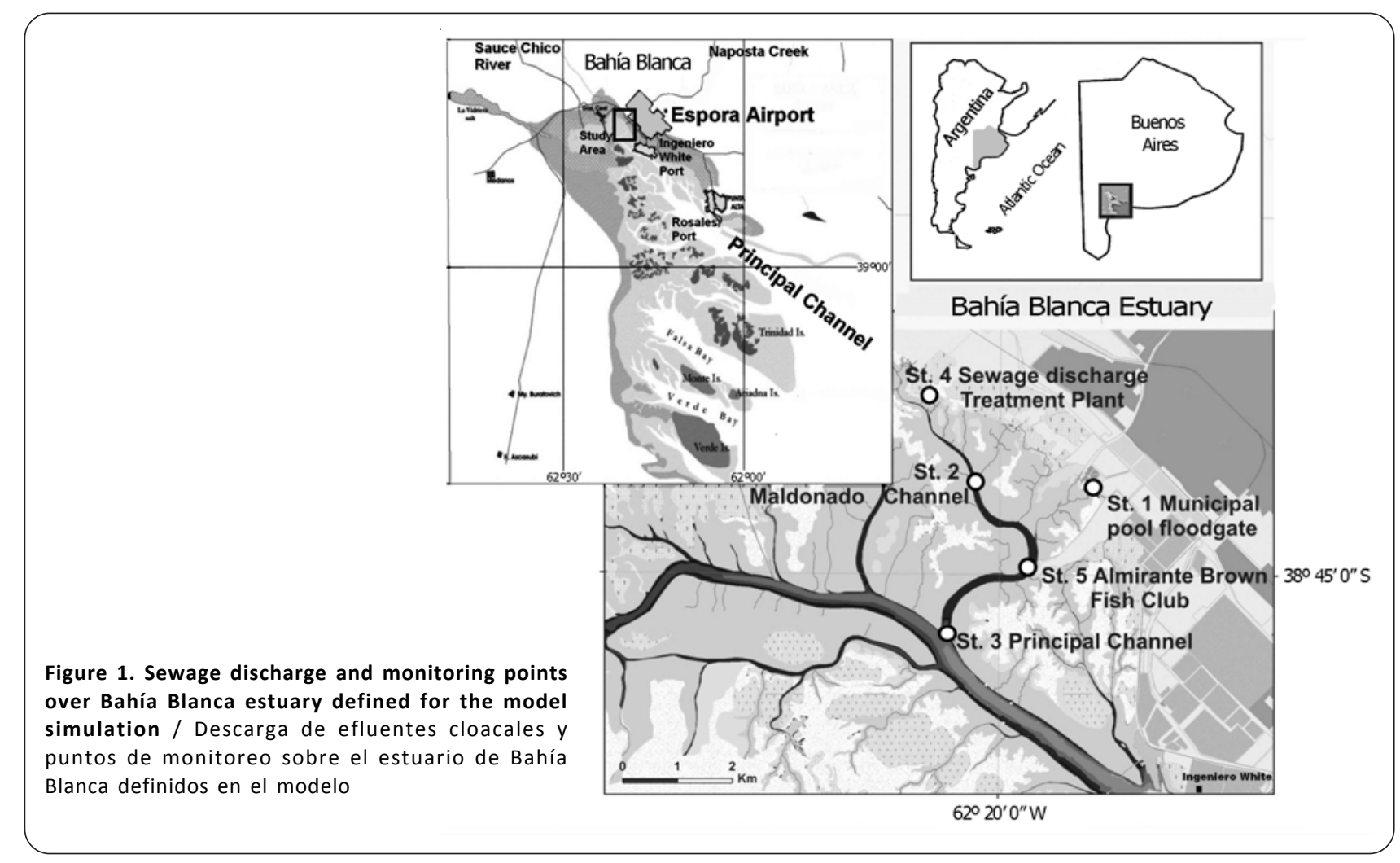

stationary tides. The mean tidal amplitude is $2.4 \mathrm{~m}$ and the tidal range and tidal current amplitude increase headward. The amplitude of the tidal wave increases with a decrease in depth of the channel. Bahía Blanca is a hyper-synchronous type estuary, where the amplitude increases steadily from the mouth to the head, implying that the convergence effect on the tidal wave is larger than the friction effect (Pierini 2007). Prevailing winds are NW-N for over $40 \%$ of the time, while SE-S winds occur $\sim 10 \%$ of the time (Piccolo et al. 1989). These wind directions are important because they blow parallel to the main channels. Wind is a major factor in the Bahía Blanca Estuary dynamics since it produces strong delays or advances of the tidal wave. The head of the estuary has a very small freshwater input, the Sauce Chico River and Napostá Grande Creek that contribute with $1 \mathrm{~m}^{3} \mathrm{~s}^{-1}$ and $0.57 \mathrm{~m}^{3} \mathrm{~s}^{-1}$, respectively (Carrica 1998) (Fig.1). The origin of both courses is in Sierra de la Ventana, about $120 \mathrm{~km}$ north from Bahía Blanca. Other creeks near Ingeniero White (Saladillo de García and Maldonado) reach the estuary with intermittent flows that become significant only during periods of local precipitation (Fig.1). The maximum (193.3 mm) and minimum (2.5 mm) monthly mean rainfall occurs in August and September, respectively (Pierini 2007).

\section{DATA AND METHODOLOGY}

During September 2009 five stations (Fig. 1) were sampled fortnightly, and since October to January 2010 weekly, coinciding with the beginning of the summer period. All sampling stations are located in the inner portion of Bahía Blanca estuary near Maldonado Municipal pool and over the principal Channel of the estuary (Fig. 1). At sites 1, 4 and 5, samples were collected at high tide in hand held $1000 \mathrm{ml}$ bottles immersed in the sea by operatives standing at the shoreline. At sites 2 and 3, samples were collected in sterile $1000 \mathrm{ml}$ bottles immersed by hand in the sea from the side of a small boat at or around high tide. The samples were collected at about $0.30 \mathrm{~m}$ below the surface in water. All samples $(n=10)$ were placed in insulated containers to $4 \pm 0.5^{\circ} \mathrm{C}$ and taken to the laboratory within $6 \mathrm{~h}$ of collection (APHA 1998, USEPA 2000). The indicator of faecal contamination EC was counted in all the samples.

For the enumeration the double layer technique was used, to recover the bacteria stressed due to the environmental conditions. The resuscitation of injured microorganisms was carried out during $2 \mathrm{~h}$ in agar plate count (PCA, Merck), and then dropping agar Endo (Merck) (Streitenberger \& Baldini 2010). The incubation was done at $44.5 \pm 0.5^{\circ} \mathrm{C}$ during $24 \mathrm{~h}$. The results were 
expressed as CFU $100 \mathrm{ml}^{-1}$. Later typical colonies were selected, isolates in PCA (Merck), and biochemically identified (McFaddin 2003).

Samples were collected to provide a reasonable number of samples collected under the real wind conditions. The sample sites were selected based on Balneario Maldonado floodgate proximity. The spatial distribution of the indicator bacteria was then evaluated using one-way completely randomized of variance (ANOVA) to determine statistically significant differences between stations.

\section{NUMERICAL MODEL}

\section{MODEL IMPLEMENTATION}

The water quality model is coupled with the hydrodynamic model (MOHID) previously described in Leitao et al. (2008), and calibrated and validated to Bahía Blanca estuary by Pierini et al. (2008); and so the same assumptions for the physical features of the system are valid here. These are: (1) the water column is not stratified (2D horizontal); (2) the hydrodynamics in the estuary are not affected by shelf water circulation. The external conditions include river discharges, forcing functions, like solar radiation and air temperature, and boundary conditions. The simulations were performed with variable T90 decay model for EC (Mateus \& Fernandes 2008), currents, temperature, salinities and sea level provided by calibrated and validated MOHID model to Bahía Blanca estuary (Pierini et al. 2008).

\section{AtMosPHERIC FORCING}

Climatological radiation levels were calculated by the model for the domain geographical coordinates. Cloud cover was also used to force the model, with monthly values taken from field observations made at Bahía Blanca meteorological station (Espora Airport 3843’58.72"S, 629’31.97"W) (Fig. 1) during 1990-2000 decade. Relative humidity, air temperature and wind were also used to force the model, with hourly values taken from field observations made at Ingeniero White meteorological

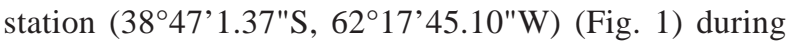
study period. Time series representations were not shown by brevity.

\section{INITIAL AND BOUNDARY CONDITIONS}

The boundary conditions (temperature, salinity, cohesive sediments and E. coli concentrations) considered for open Atlantic boundaries and the initial conditions for the model are given in Table 1. Model simulations reproduced a sewage discharge (SD) in the inner part of Bahía Blanca estuary. There are other creeks flowing into the Bahía Blanca Estuary, as Saladillo de García and Maldonado creeks with an overall flow lower than Napostá Creek itself (Pierini 2007) (Fig. 1). Official data obtained made available by ABSA (Aguas Bonaerenses S. A.) estimates a discharge of $0.575 \mathrm{~m}^{3} \mathrm{~s}^{-1}$ on average, although on the other hand Piccolo \& Perillo (1990) estimated a discharge of $10 \mathrm{~m}^{3} \mathrm{~s}^{-1}$ and sometimes higher than this value. Maldonado Channel is a waterway used eventually when Napostá River reaches flows over $30 \mathrm{~m}^{3}$ $\mathrm{s}^{-1}$, preventing floodings by deviation of part of the water. This channel is used during strong torrential rains and the maximum flow on average conditions is $3.6 \mathrm{~m}^{3} \mathrm{~s}^{-1}$.

The pollution point sources used in the model were determined based on current information on the sanitary conditions of the basin, so that the development of a numerical reference scenario for the current situation could therefore be established. The model considers one sewage discharge point (SD) with a $10^{7} \mathrm{CFU} 100 \mathrm{ml}^{-1} \mathrm{EC}$ concentration, corresponding to the new sewage treatment plant in the estuary (Fig. 1, Tables 1 and 2).

MOHID simulates two types of sediment, cohesive and non-cohesive. Since bacteria tend to attach to fine particles, only cohesive sediment was considered in this study. The MOHID model is able to simulate cohesive sediment transport, by combining the advection-diffusion

\begin{tabular}{|c|c|c|c|}
\hline Properties & Units & Initial conditions & Boundary conditions \\
\hline Temperature & ${ }^{\circ} \mathrm{C}$ & 19 & 19 \\
\hline Salinity & psu & 20 & 35 \\
\hline Cohesive sediments & $\mathrm{mg} \mathrm{l}^{-1}$ & 90 & 25 \\
\hline E. coli & CFU $100 \mathrm{ml}^{-1}$ & 0 & 0 \\
\hline
\end{tabular}

Table 2. E. coli concentration and the respective effluent flow $\left(\mathrm{m}^{3}\right.$ $\mathrm{s}^{-1}$ ) in sewage drainage area (SD) and Naposta Creek flow / Área de descarga, concentración de $E$. coli y flujos de efluentes $\left(\mathrm{m}^{3} \mathrm{~s}^{-1}\right)$ en el área de drenaje de residuos cloacales (SD) y en el Arroyo Napostá

\begin{tabular}{lcc}
\hline Discharge & CFU E. coli $100 \mathrm{ml}^{-1}$ & Flow m $\mathrm{s}^{-1}$ \\
\hline SD (Maldonado) & 10000000 & 0.21 \\
Naposta Creek & 1250 & 0.57 \\
Saladillo de García & 1000 & 0.01 \\
\hline
\end{tabular}


module for simulating the transport in the water column and the free vertical movement module to compute the settling velocity, therefore, the vertical displacement of the suspended particles. The settling velocity was computed by NEDECO ARCONSULT $\left(1983^{2}\right)$ as $1 \cdot 10^{-4} \mathrm{~ms}^{-1}$. All discharges are characterized by a cohesive sediment concentration of $90 \mathrm{mg} \mathrm{l}^{-1}$, salinity 0.5 and temperature of $19^{\circ} \mathrm{C}$ (Table 1$)$.

\section{LAGRANGIAN MODEL}

Lagrangian transport models are very useful to simulate localized processes with sharp gradients, such as submarine outfalls, sediment erosion due to dredging works, hydrodynamic calibration, oil dispersion and water quality (Mateus \& Fernandez 2008). The MOHID model uses the concept of lagrangian tracers to assess the spatial-temporal evolution of the contamination plume, determined by tidal regime and local circulation. Tracers are transported by currents calculated by hydrodynamic model and each tracer has the ability to be associated with one or more properties (physical, chemical or biological). This module is a subset of the MOHID modelling system and has been used in other instances also to study pollutant dispersion (Gomez-Gesteira et al. 1999). At the present stage the model is able to simulate water quality evolution, oil dispersion and sediment transport. The lagrangian module interacts with other modules such as the EC decay. Sediment transport can be associated directly to tracers using the concept of settling velocity.

The reduction of faecal contaminant loads in the water is achieved by a combination of 3 main factors: initial dilution, dispersion and bacterial decay. Dynamic models usually take into consideration the physical processes of dilution and dispersion but frequently ignore the influence of abiotic effects on bacteria mortality by assuming a fixed mortality rate. Under certain conditions, this limitation hinders the results. For the specific case of the decline in faecal indicator bacteria, several studies have shown a particularly relevant role of abiotic factors like temperature, salinity and irradiance (Sarikaya \& Saatci 1995, Serrano et al. 1998). A more realistic assessment of temporal and spatial faecal contamination can be achieved by using a feacal decay model with a dynamic T90 as a function of instant solar radiation, water temperature and salinity. Faecal dispersion can be simulated using both the lagrangian and the eulerian transport schemes, while hydrodynamics and ambient properties as temperature, salinity and solar radiation is calculated by a eulerian approach, the discharges and evolution is lagrangian oriented. Particles properties are affected by the involving environment.

\section{COLIFORM MODEL}

The faecal model takes into account the effect on mortality of these organisms due to a shift on environmental factors. Faecal coliforms original habitat is in the intestine of mammals and birds. Their mortality rate increases when they are exposed to high salinities, high temperatures and the solar radiation (Alkan et al. 1995, Sampson et al. 2006). The indicator-bacteria die-off rate is represented by a first order equation (Chick's Law for disinfection), which states that the rate of loss is proportional to the concentration:

$$
\frac{d N}{d t}=-k N
$$

where $N$ is the initial bacterial concentration in the effluent and $k$, the first-order decay rate $\left(\right.$ day $\left.^{-1}\right)$ or die-off coefficient, usually described in the form of a sum of the contribution of individual parameter:

$$
k=k_{b}+k_{i}
$$

with $k_{b}$ as the base mortality as a function of temperature and salinity and $k_{i}$ the death rate due to solar radiation. Canteras et al. (1995) obtained for the Cantabrian Sea the following expression:

$$
k=2.533 \times 1.040^{(\mathrm{T}-20)} \times 1.012^{\mathrm{S}}+0.113 \mathrm{i}_{\mathrm{z}}
$$

where $\mathrm{T}$ is the water temperature $\left({ }^{\circ} \mathrm{C}\right), S$ is the surrounding water salinity (psu) and $i_{x}$ is the radiation (watt $\mathrm{m}^{-2}$ ) at depth $z(\mathrm{~m})$. As the present model application is twodimensional the solar radiation is averaged with depth $\mathrm{z}$ (m).

In the present application, since only one horizontal layer is assumed, the radiation used in the mortality model is the integration in depth of the light radiance at the sea surface. It must be stressed that this approach relies on the basic assumptions usually made with respect to the effect of radiation on faecal contamination in water systems (Mancini 1978), a mortality rate following a firstorder kinetics and linearly dependent upon solar radiation

${ }^{2}$ NEDECO-ARCONSULT. 1983. Estudio de dragado del canal de acceso al Puerto de Bahía Blanca, Informe Final (Technical Report).

3 volúmenes, Buenos Aires, 845 pp. 
intensity, and its lethal effect additive to, but independent, of the effect of other parameters.

The EC model was ran under summer conditions for the $\mathrm{SD}$, the new plant that treats wastewaters from the Bahía Blanca city with a discharge of $0.21 \mathrm{~m}^{3} \mathrm{~s}^{-1}$ and concentrations from collected data of $1.10^{7} \mathrm{CFU} 100 \mathrm{mg} \mathrm{l}^{-1}$. The flux was estimated from the local population impacting the area. Water calculated concentrations were vertically averaged on each point after a continuous EC input, and included the biological decay rate effect.

\section{Model VALIDATION}

The model results were validated with EC field data from campaigns carried out in September 2009 until January 2010. These analyses allowed the identification of the degree of faecal contamination in the water, especially in the interior of the Bahía Blanca Estuarine System.

Mean Bias (MB) indicates the average difference between the observed and predicted values. Predicted EC concentrations vary in (bias/total EC*100) \% of the total EC at 1, 2, 3, 4 and 5 station, respectively. The Root Mean Square Error (RMSE) provides an estimate of the magnitude of the model. The RMSE is the square root of the variance which represents that $95 \%$ of the model predictions do not differ (in absolute value) from the observations by more than 2xRMSE. Skill (or index of agreement) aims to quantify the 'predictive skill' between model results and observations by using the next formula:

$$
\text { Skill }=1-\frac{\sum_{i=1}^{N}\left(X_{\text {Mod_i }_{i} i}-X_{\text {Obs_i }_{-}}\right)^{2}}{\sum_{i=1}^{N}\left(\left|X_{\text {Mod_i }_{-}}-\bar{X}_{\text {Obs }}\right|+\left|X_{\text {Obs }_{-} i}-\bar{X}_{\text {Obs }}\right|\right)^{2}} 0 \leq \text { Skill } \leq 1
$$

where $\mathrm{X}$ is the variable being compared (in this case the EC concentrations) and $\mathrm{X}_{\text {Mod_i } i}$ is the model result for the instant $i, \mathrm{X}_{\text {Obs } \_i}$ is observation result for the instant $i$, the $\overline{\mathrm{X}}_{\mathrm{Obs}}$ is the mean of the observations and $\mathrm{N}$ is the number of observations. The skill parameter can be seen as a way of normalizing the model error. The skill index (or index of agreement) intended to be a descriptive measure, and is both a relative and bounded measure which can be widely applied in order to make cross-comparisons between models. It provides similar information than the coefficient of determination, in the sense that gives a measure of the model performance, but it penalises models with greater bias. If the skill index is one the model presents an optimal predictive skill. Skill values for each station are close to one, indicating a high degree of model performance.

\section{Results}

Considering the objective of this study, the health of the marine water bodies along the inner part of Bahía Blanca estuary was assessed with special attention to an EC dispersion using a numerical model and it influence over the Municipal pool into the Bahía Blanca Estuarine system. Five points inside the Bahía Blanca Estuary (Fig. 1) were chosen for the output of model results in order to simplify the analyses. Field data from these stations was used to perform the validation (Table 3).

The EC concentration in the water has not shown a statistically significant spatial variation $(P>0.05$, Table 4). In floodgate (station 1 ) values observed are higher than level suggested by USEPA (2000) for recreational water (mean: $126 \mathrm{CFU} 100 \mathrm{ml}^{-1}$ ), being the most critical in terms of concentration of EC (mean: $701 \mathrm{CFU} 100 \mathrm{ml}^{-1}$ ) (Table 3). This higher concentration of EC can be associated with the amount of sewage discharges.

Table 3. E. coli concentration (CFU $100 \mathrm{ml}^{-1}$ ) observed and modeled with MOHID / Concentración de E. coli (UFC $100 \mathrm{ml}^{-1}$ ) observada y modelada con MOHID

\begin{tabular}{rrrrrrrrrrr}
\hline \multirow{2}{*}{ Date } & \multicolumn{2}{c}{ St. 1 } & \multicolumn{2}{c}{ St. 2} & \multicolumn{2}{c}{ St. 3 } & \multicolumn{2}{c}{ St. 4} & \multicolumn{2}{c}{ St. 5 } \\
& Obs & Mod & Obs & Mod & Obs & Mod & Obs & Mod & Obs & Mod \\
\hline $17 / 09 / 09$ & 2000 & 2650 & 1200 & 1000 & 400 & 250 & 7750000 & 7700000 & 400 & 650 \\
$08 / 10 / 09$ & 100 & 280 & 600 & 725 & 100 & 300 & 9300000 & 9000000 & 200 & 280 \\
$27 / 10 / 09$ & 100 & 150 & 300 & 440 & 200 & 250 & 4000000 & 3900000 & 100 & 150 \\
$12 / 11 / 09$ & 10 & 20 & 10 & 50 & 500 & 450 & 1500000 & 1450000 & 100 & 170 \\
$09 / 12 / 09$ & 700 & 650 & 100 & 90 & 200 & 380 & 1350000 & 1320000 & 300 & 380 \\
$22 / 12 / 09$ & 1200 & 1150 & 200 & 174 & 100 & 240 & 1100000 & 1150000 & 300 & 420 \\
$28 / 12 / 09$ & 600 & 620 & 300 & 440 & 100 & 190 & 6700000 & 5400000 & 200 & 250 \\
$06 / 01 / 10$ & 900 & 1020 & 100 & 50 & 200 & 320 & 3200000 & 2900000 & 100 & 140 \\
$18 / 01 / 10$ & 1000 & 945 & 800 & 923 & 150 & 230 & 3300000 & 3150000 & 2200 & 1700 \\
$01 / 02 / 10$ & 400 & 550 & 1000 & 875 & 300 & 280 & 2500000 & 2450000 & 500 & 550 \\
Mean & 701 & 803 & 461 & 477 & 225 & 289 & 4070000 & 3842000 & 440 & 469 \\
\hline
\end{tabular}


Table 4. One-way completely randomized analysis of variance (ANOVA) to determine statistical significant differences between stations / Análisis de Varianza (ANDEVA) para determinar diferencias estadísticamente significativas entre estaciones

\begin{tabular}{lrrrrrr}
\hline & \multicolumn{7}{c}{ ANOVA } \\
Source of Variation & \multicolumn{1}{c}{ SS } & d.f & MS & F & $P$ & Critic value \\
\hline Between groups & 1.22 & 4 & 0.41 & 0.89 & 0.45 & 2.79 \\
Within groups & 22.49 & 5 & 0.46 & & & \\
Total & 23.71 & 9 & & & & \\
\hline
\end{tabular}

To evaluate the predictive capability of the water quality model, 6 months simulation was performed. The results of the model were compared with microorganism abundance measurements (Table 5). Observed and computed indicator organism counts were compared in several ways. In addition, differences between the model and data at the stations were quantified as mean error and root mean square error. The mean error is the average difference in predicted and observed organism counts. A negative value indicates that the model underpredicts the data, whereas a positive indicates an overprediction. The extent of bias is indicated by the magnitude of the error (Table 5).

Applying these conditions to the model, correlations between the EC observed and model results obtained were performed obtaining correlation coefficients between 0.38-0.95 (Table 5). To further evaluate the comparison between the observed EC with the predicted EC obtained through modelling, the additional indicators suggested by Willmott (1982) were assessed (Table 5).

All comparisons were between the EC concentration on the modelling data and the observed values. Comparisons of the distributions of EC at five stations are presented in Table 3. The concentrations of bacteria at stations 1, 2, 3 and 5 exceeded the levels proposed by the USEPA (2000) for recreational waters, while in the station 4 (sewage discharge) the levels are 3 orders of magnitude higher than permitted by the $\mathrm{ADA}^{3}$ (Autoridad del Agua 2003) for discharge in estuaries. Figures 2a and $2 \mathrm{~b}$ shows the spatial distribution of EC bacteria derived from the application of MOHID during ebb and flood tide.
Table 5. Statistical performance between E. coli observed and modeled at each station during measurement time / Representación estadística entre los recuentos de $E$. coli observados y modelados en cada estación durante el tiempo de medición

\begin{tabular}{lrrrrr}
\hline & \multicolumn{5}{c}{ Stations } \\
& \multicolumn{1}{c}{1} & \multicolumn{1}{c}{2} & 3 & \multicolumn{1}{c}{4} & \multicolumn{1}{c}{5} \\
\hline Correlation (r) & 0.94 & 0.93 & 0.38 & 0.95 & 0.94 \\
Coef. determination ( $\mathrm{r}^{2}$ ) & 0.88 & 0.86 & 0.14 & 0.90 & 0.88 \\
Mean Bias & 103 & 241 & 64 & -228000 & 29 \\
Root mean square error & 1025 & 461 & 202 & 720999 & 92 \\
Skill & 0.97 & 0.91 & 0.67 & 0.99 & 0.97 \\
\hline
\end{tabular}

In general, data and mean values of the model are similar, indicating that the model accurately reproduces both the variability and the mean concentration at each station (Table 3). Exceptions include station 3, where the model tends to exceed the data. However, even at this station, the trend is similar but its proximity to the main channel can make the difference. The visual comparisons are supported by the mean error (Table 5).

\section{Discussion}

In this study, EC was the bacterial indicator associated with the observed water quality. The greater numbers of EC into Bahía Blanca estuary are of interest because these waters feed the Municipal pool, causing an environmental health concern to people and authorities.

Statistical analysis found that differences in EC counts among sampling sites are no significant. Coincidentally MOHID model proposes that in flood tide there is a trend of the plume to be distributed evenly on the tidal flats of the study area, reaching the Municipal pool floodgate, during flow tide conditions. This effect increases with persistent southerly wind, preventing the pollutant load continue to the main channel, increasing the residence time in the area, Figures 2a and 2b show this behavior during the ebb and flow tide.

Then, a numerical model was implemented to describe the transport and fate of faecal organisms within this complex coastal environment. The far field model incorporated the near field plume dynamics of the wastewater treatment plant to accurately define the transport of bacterial indicators in the vicinity of sewage

${ }^{3}$ ADA. 2003. Provincia de Buenos Aires. Resolución N³36/2003. Anexo II. Autoridad del agua. <http://www.estrucplan.com.ar/ Formularios/Result.asp?Tema=Efluentes Líquidos\&Mail=1> 


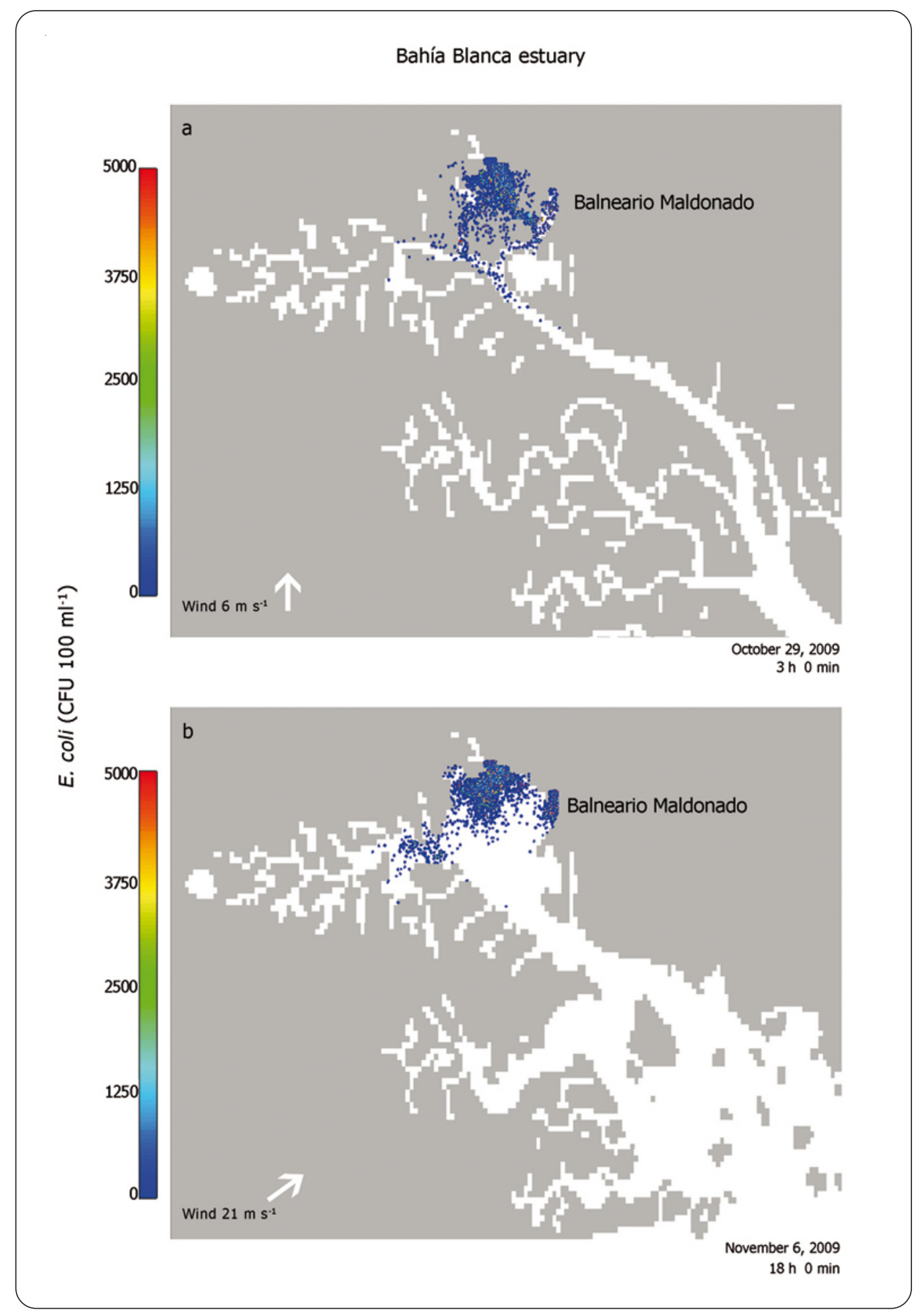

Figure 2. Spatial E. coli distribution with MOHID numerical model during a) ebb tide and b) flood tide, with direction and intensity wind / Distribución espacial de E. coli con el modelo numérico MOHID durante a) marea baja y b) marea alta, con la dirección e intensidad del viento 
discharges. The model was calibrated and successfully reproduced water level, currents, temperature and salinities observed within the estuary (Pierini et al. 2008). The fate models accurately predicted both the variability and means indicator organism counts at most stations and show the environmental impact over the Municipal pool.

The major contributions in this study are: (1) The MOHID model provides an approach to fully simulate the transport of faecal bacteria associated with other processes (currents, wind, sediment, etc). (2) The sediment contribution over the behavior fecal bacteria can be explicitly modeled and providing more information for the management of faecal contamination. (3) The case study showed that the model simulated correctly the EC transport under implemented conditions and the results are in good agreement with measured observations. (4) The model captures the spatial-temporal patterns of EC dynamics in the system. However, the results showed the importance of considering the origin of the raw sewage discharge in future facilities for a better reproduction of the coliform behavior in this area. (5) The model was capable of predicting complex two dimensional flow features and provided a rationale tool for environmental decision making. The predictions of the MOHID model described herein are expected to compose a useful tool for the efforts to reduce the pollution in the Bahía Blanca estuary.

Therefore, it is recommended that more research is mandatory to achieve an effective assessment of the role of this contribution in modelling simulations. Even though the solution of the model is integral to the water column, the comparisons between measures and model results were satisfactory, especially near the floodgate.

The validation outcome for the dispersion of microbiological plumes has been positive, but the need for a more advanced validation process, based on a broader and systematic field monitoring is evident. Although this sort of ongoing monitoring is an expensive effort, the results are fundamental for a proper understanding of the system's functioning, therefore fundamental for a best calibration and validation of the numerical models in the study area. Together, more field data and modelling simulations will increase the knowledge of the microbiological behavior in the inner part of the estuary. This is of paramount importance to determine spatial-temporal variation in faecal concentrations with more precision and, consequently, perfecting the decision maker's capability of the modelling system. Such a system is required for a proper water quality management of the Bahía Blanca estuary, given that the source of much of its contamination is located inside the estuary, as suggested by field data and supported by model results.

\section{ACKNowledgments}

Executive Technical Committee of Bahía Blanca City, which subsidized the campaigns and contributed to carrying out of the samples. The authors wish to acknowledge the helpful comments provided by the reviewers.

\section{LiteratuRe Cited}

Alkan U, D Elliott \& L Evison. 1995. Survival of enteric bacteria in relation to simulated solar radiation and other environmental factors in marine waters. Water Research 29: 2071-2080.

APHA. 1998. Standard methods for the examination of water and wastewater, 2000 pp. American Public Health Association, Washington.

Burkhardt III W, KR Calci, WD Watkins, SR Rippey \& SJ Chirtel. 2000. Inactivation of indicador microorganisms in estuarine waters. Water Research 34: 2207-2214.

Canteras JC, JJ Juanes, L Pérez \& K Koev. 1995. Modelling the coliforms inactivation rates in the Cantabrian Sea (Gulf of Biscay) from in situ and laboratory determinations of T90. Water Science and Technology 32: 37-44.

Carrica J. 1998. Hidrogeología de la cuenca del Arroyo Napostá Grande, Provincia de Buenos Aires. Ph.D. thesis, University Nacional del Sur, Bahía Blanca, 215 pp.

Chigbu P, S Gordon \& TR Strange. 2005. Fecal coliform bacteria disappearance rates in a north-central Gulf of Mexico estuary. Estuarine, Coastal and Shelf Science 65: 309-318.

Coelho H, R Neves, M White, PC Leitão \& A Santos. 2002. A model for ocean circulation on the Iberian coast. Journal of Marine Systems 32: 153-179.

Field KG \& M Samadpour. 2007. Fecal source tracking, the indicator paradigm, and managing water quality. Water Research 41: 3517-3538.

Fleisher JM, D Kay, RL Salmon, F Jones, M Wyer \& AF Godfree. 1996. Marine waters contaminated with domestic sewage: nonenteric illnesses associated with bather exposure in the United Kingdom. American Journal of Public Health 86: $1228-1234$.

Frick W, LP Roberts, J Davis, D Keyes \& KG Baumgartner. 2001. Dilution model for effluent discharges, (visual plumes), 137 pp. Environmental Research Division, NERL, ORD, U.S. Environmental Protection Agency, Standards and Applied Division Office of Science and Technology, Washington. 
Fries S, G Characklis \& R Noble. 2006. Attachment of fecal indicator bacteria to particles in the Neuse River Estuary, N.C. Journal of Environmental Engineering 132: 1338-1345.

Gomez-Gesteira M, P Montero, R Prego, J Taboada, P Leitao, M Ruiz-Villarreal, $R$ Neves \& V Perez-Villa. 1999. A two-dimensional particle tracking model for pollution dispersion in A Coruña and Vigo Rias (NW Spain). Oceanologica Acta 22: 167-177.

Kay D, JM Fleisher, RL Salmon, F Jones, MD Wyer, AF Godfree, Z Zelenauch-Jacquotte \& R Shore. 1994. Predicting likelihood of gastroenteritis from sea bathing: results from randomised exposure. The Lancet 344: 905909.

Leitao P, M Mateus, L Braunschweig, L Fernandes \& $\mathbf{R}$ Neves. 2008. Modelling coastal systems: The MOHID Water Numerical Lab. In: Neves R, J Baretta \& M Mateus (eds). Perspectives on integrated coastal zone management in South America, pp. 77-88. IST Press, Lisbon.

Malhadas SM. 2008. Modelacao do impacte de emissarios submarinos em zonas costeiras-caso da Foz do Arelho. Msc. Thesis, IST, Universidad Técnica de Lisboa, Lisboa, 95 pp.

Mancini JL. 1978. Numerical estimates of coliform mortality rates under various conditions. Journal of Water Pollution Control Federation 50: 2477-2484.

Martins MT, M Sato, NC Alves, VM Stoppe, P Prado \& S Sanchez. 1995. Assessment of microbiological quality for swimming pools in South America. Water Research 29: $2417-$ 2420.

Mateus M \& R Fernandes. 2008. Modelling pollution: Oil spills and faecal contamination. In: Neves R, J Baretta \& M Mateus (eds). Perspectives on integrated coastal zone management in South America, pp. 89-96. IST Press, Lisbon.

McFaddin JF. 2003. Pruebas bioquímicas para la identificación de bacterias de importancia clínica, 850 pp. Editorial Panamericana, Buenos Aires.

Melo WD. 2004. Orígenes morfológicos. En: Píccolo MC \& M Hoffmeyer (eds). Ecosistema del estuario de Bahía Blanca, pp. 21-27. Instituto Argentino de Oceanografía, Bahía Blanca.

Piccolo C \& G Perillo. 1990. Physical characteristics of the Bahía Blanca Estuary (Argentine). Estuarine, Coastal and Shelf Science 31: 303-317.

Piccolo MC, A Capelli de Steffens \& A Campo de Ferreras. 1989. Variación espacial del viento en el área de Bahía Blanca. Revista Geofísica, IPGH, México 31: 205-220.

Pierini J. 2007. Circulación y transporte en zonas costeras del estuario de Bahía Blanca. Tesis doctoral, Universidad Nacional de Buenos, Buenos Aires, 209 pp.
Pierini J, F Campuzano, J Marcovecchio \& G Perillo. 2008. The application of MOHID to assess the potential effect of sewage discharge system at Bahía Blanca estuary (Argentina). In: Neves R, J Baretta \& M Mateus (eds). Perspectives on integrated coastal zone management in South America, pp. 515-522. IST Press, Lisbon.

Rodriguez C, M Mancini, C Prósperi, A Weyers, G Alcantú \& S Ferrero. 2002. Variaciones estacionales de la calidad del agua del río Chocancharava (río Cuarto), Córdoba, Argentina. Ecologia Austral 12: 65-72.

Rossen A, MI Rodríguez, AL Ruibal-Conti, ML Fortunato, A Bustamante \& M Ruiz. 2008. Indicadores bacterianos de contaminación fecal en el embalse San Roque (Córdoba, Argentina). Higiene, Sanidad y Ambiente 8: 325-330.

Sampson RW, SA Swiatnicki, VL Osinga, JL Supita, CM McDermott \& GT Kleinheinz. 2006. Effects of temperature and sand on $E$. coli survival in a northern lake water microcosm. Journal of Water and Health 4:389-393.

Sarikaya HZ \& AM Saatci. 1995. Bacterial die-away rates in Red Sea waters. Water Science and Technology 32: 45-52.

Serrano E, B Moreno, M Solaun, JJ Aurrekoetxea \& J Ibarluzea. 1998. The influence of environmental factors on microbiological factors on microbiological indicators of coastal water pollution. Water Science and Technology 38: 195-199.

Soller JA, ME Schoen, T Bartrand, JE Ravenscroft \& NJ Ashbol. 2010. Estimated human risks from exposure to recreational waters impacted by human and non-human sources of faecal contamination. Water Research 44: 46744691.

Streitenberger ME \& MD Baldini. 2010. Deterioro de un área recreacional por efectos del volcado de líquidos cloacales. Revista Argentina de Microbiología 42: 307-310.

USEPA. 2000. Improved enumeration methods for the recreational water quality indicators: Enterococci and Escherichia coli. EPA-821-R-97-004. USA Office of Science and Technology, Washington, 49 pp.

Viegas CN, S Nunes, R Fernandes \& R Neves. 2009. Streams contribution on bathing water quality after rainfall events in Costa do Estoril- a tool to implement an alert system for bathing water. Journal of Coastal Research Special Issue 56: 1691-1695.

Willmott C. 1982. Some comments on the evaluation of model performance. Bulletin of the American Meteorological Society 63: 1309-1313.

Received 29 December 2011 and accepted 10 May 2012

Associate Editor: Mauricio Landaeta D. 